\title{
Commission on Cancer
}

National Cancer Institute

\section{Source}

National Cancer Institute. Commission on Cancer. NCI Thesaurus. Code C68607.

A consortium of professional org anizations dedicated to improving survival and quality of life for cancer patients through standard-setting, prevention, research, education, and the monitoring of comprehensive quality care. 